\title{
Notable postnatal alterations in the myenteric plexus of normal human bowel
}

\author{
T Wester, D S O’Briain, P Puri
}

\begin{abstract}
Background-Nitric oxide is the most important transmitter in non-adrenergic non-cholinergic nerves in the human gastrointestinal tract. Impaired nitrergic innervation has been described in Hirschsprung's disease, hypertrophic pyloric stenosis, and intestinal neuronal dysplasia (IND). Recent findings indicate that hyperganglionosis, one of the major criteria of IND, is age dependent. However, information is scanty regarding the neurone density in normal human bowel in the paediatric age group.

Aims-To determine neurone density, morphology, and nitric oxide synthase distribution of the normal myenteric plexus at different ages during infancy and childhood.
\end{abstract}

Methods-Specimens were obtained from small bowel and colon in 20 children, aged one day to 15 years, at postmortem examination. Whole mount preparations were made of the myenteric plexus, which were subsequently stained using NADPH diaphorase histochemistry (identical to nitric oxide synthase) and cuprolinic blue (a general neuronal marker). The morphology of the myenteric plexus was described and the neurone density estimated.

Results-The myenteric plexus meshwork becomes less dense during the first years of life. The density of ganglion cells in the myenteric plexus decreases significantly with age during the first three to four years of life. The NADPH diaphorase positive (nitrergic) subpopulation represents about $34 \%$ of all neurones in the myenteric plexus.

Conclusions-The notable decrease in neurone density in the myenteric plexus during the first years of life indicates that development is still an ongoing process in the postnatal enteric nervous system. Applied to the clinical situation, this implies that interpretation of enteric nervous system pathology is dependent on the age of the patient.

(Gut 1999;44:666-674)

Keywords: whole mount preparation; myenteric plexus; nitric oxide; neurone density; development; human

In recent years, it has become evident that nitric oxide (NO) is the primary mediator of non-adrenergic non-cholinergic (NANC) neurotransmission in the gastrointestinal tract in various species. ${ }^{1} \mathrm{NO}$ containing nerves may be shown by nicotinamide adenine dinucleotide phosphate (reduced form, NADPH) diaphorase histochemistry, described by SchererSingler and colleagues ${ }^{2}$ in 1983, which stains a subpopulation of neurones which colocalise with the NO producing enzyme nitric oxide synthase (NOS) in the brain and peripheral neuronal tissue. ${ }^{34}$

Abnormalities in these newly recognised NO producing neurones may contribute to the pathogenesis in various gastrointestinal disorders. Deficient NADPH diaphorase activity has been described in nerve fibres in the pyloric muscle in hypertrophic pyloric stenosis. ${ }^{5} \mathrm{Ni}-$ trergic neurones are absent in the aganglionic bowel of Hirschsprung's disease (HD), which also lacks NADPH diaphorase positive fibres in the circular muscle layer. ${ }^{67}$ Recent findings also indicate that the nitrergic innervation of the circular muscle layer is abnormal in intestinal neuronal dysplasia (IND). ${ }^{8}$

IND was first described by Meier-Ruge ${ }^{9}$ in 1971 in children who presented with clinical symptoms resembling HD. However, the criteria for the diagnosis of IND remain controversial and several authors have raised doubts about its existence as a distinct histopathological entity. ${ }^{10} 11$ In particular, it has been suggested that proposed diagnostic criteria relating to nerve cell density may overlap with age related changes. ${ }^{12}{ }^{13}$ An important reason for the existing confusion is the incomplete knowledge of the morphology of the normal human enteric nervous system.

Information regarding the postnatal maturation of the enteric nervous system is scanty, although it has implications for the interpretation of histopathological findings in early childhood. The purpose of this study was to describe the morphology of nitrergic nerve bundles and estimate the density of NADPH diaphorase positive nerve cells in the myenteric plexus of normal human small bowel and colon at different ages during infancy and childhood. The size of the NADPH diaphorase positive population of nerve cells was also estimated in relation to the number of cells stained by cuprolinic blue, which is a global nerve cell marker in the myenteric plexus. ${ }^{14}$ Estimates of nerve cell density are heavily influenced by section thickness in conventional histological preparations. This variable was eliminated by

Abbreviations used in this paper: HD,

Hirschsprung's disease; IND, intestinal neuronal dysplasia; NANC, non-adrenergic, non-cholinergic; NO, nitric oxide; NOS, nitric oxide synthase; VIP, vasoactive intestinal polypeptide; ATP, adenosine triphosphate; NSE, neurone specific enolase; PGP, protein gene product. 
use of the highly informative whole mount technique which reveals all the cells in a given segment of bowel.

\section{Methods}

Specimens were obtained at postmortem examination of 20 full term infants and children, aged one day to 15 years, who died of non-gastrointestinal causes. Seven autopsies were performed within 12 hours after death, and nine between 13 and 24 hours after death. Four postmortem examinations were performed 25 to 48 hours after death, a delay which, however, seemed to have limited influence on the staining results. ${ }^{15}$ Segments of bowel from proximal jejunum $(30-60 \mathrm{~cm}$ distal to the ligament of Treitz), distal ileum (30-60 $\mathrm{cm}$ proximal to the ileocaecal valve), proximal colon (ascending colon), midcolon (transverse colon), and distal colon (descending and sigmoid colon) were taken. The rectum was dissected down to the mucocutaneous line and divided. Specimens were also obtained from two 36 gestational week premature infants, who died soon after birth of diaphragmatic hernia and congenital heart malformation, respectively. Both had a bowel rotation anomaly, and the child with diaphragmatic hernia had meconium peritonitis from a small bowel perforation. In these cases, specimens from jejunum, proximal colon, distal colon, and rectum were examined. Surgical specimens were obtained from rectosigmoid colon in four patients with HD, aged 1-11 months, at the time of pull through operation.

TISSUE PREPARATION

All specimens were opened along the mesenteric border and rinsed. The bowel was cut into $2 \times 2 \mathrm{~cm}$ pieces. Selected specimens were prefixed, without stretching, in paraformaldehyde $4 \%$ in $0.1 \mathrm{M}$ phosphate buffer ( $\mathrm{pH} 7.3$ ) overnight at $+4^{\circ} \mathrm{C}$, rinsed in $0.01 \mathrm{M}$ phosphate buffered saline (PBS), and stored at $-70^{\circ} \mathrm{C}$ until they were used. For cuprolinic blue staining, specimens were prefixed, without stretching, in a modified Carnoy's solution, containing $63 \%$ ethanol, $32 \%$ chloroform, and $5 \%$ acetic acid, ${ }^{16}$ for one hour at room temperature followed by rinsing in PBS and subsequently stored in $70 \%$ ethanol or frozen at $-70^{\circ} \mathrm{C}$ until use.

Whole mount preparations were made using fine pointed forceps, microsurgical scissors, and a dissection microscope. Initially, the serosa was removed, followed by separation of the muscular layers from the submucosal layer. Subsequently, the circular muscle layer was peeled off the longitudinal muscle layer to which the myenteric plexus adheres.

\section{NADPH DIAPHORASE HISTOCHEMISTRY}

For NADPH diaphorase histochemistry, the longitudinal muscle myenteric plexus laminae were pinned flat and slightly stretched on silicone elastomer (Sylgard, Dow Corning, Wiesbaden, Germany) in plastic dishes. The specimens were incubated in a staining solution containing $\beta-\mathrm{NADPH}$ (Sigma Chemical Co, Dorset, UK) $1 \mathrm{mg} / \mathrm{ml}$, nitroblue tetrazo- lium (Sigma) $0.25 \mathrm{mg} / \mathrm{ml}$, and $0.3 \%$ Triton $\mathrm{X}-100$ in $0.05 \mathrm{M}$ Tris- $\mathrm{HCl}$ buffer $(\mathrm{pH} \mathrm{7.6)}$ for one to two hours at $37^{\circ} \mathrm{C}$. The staining intensity was checked under the dissection microscope and the process was stopped by rinsing in PBS. The laminae were subsequently mounted on microscopic slides in Glycergel (Dako, Glostrup, Denmark). Negative controls omitting NADPH were performed.

CUPROLINIC BLUE STAINING

For cuprolinic blue staining longitudinal muscle myenteric plexus laminae were placed on microscopic slides where they were allowed to dry, followed by staining as described by Heinicke et al. ${ }^{17}$ The staining solution contained $0.3 \%$ cuprolinic blue (quinolinic phthalocyanine, Polysciences, Warrington, Pennsylvania, USA) in $0.025 \mathrm{M}$ sodium acetate buffer $(\mathrm{pH}$ 5.6), to which magnesium chloride was added (2.03 $\mathrm{g} \mathrm{MgCl}_{2} \cdot 6 \mathrm{H}_{2} \mathrm{O}$ to $10 \mathrm{ml}$ of dye solution) to give a $1.0 \mathrm{M}$ solution. The solution was applied to the specimens for 60 minutes at room temperature, followed by rinsing in water and immersion in sodium acetate buffer 0.025 $\mathrm{M}$ (pH 5.6) with $\mathrm{Mg}_{2} \mathrm{Cl}$ added to give a $1.0 \mathrm{M}$ solution for 30 minutes. The specimens were rinsed in water, dehydrated in ethanol, cleared in xylene, and mounted in DPX (BDH, Poole, Dorset, UK).

ANALYSIS OF THE RESULTS

For calculation of the neurone density, a light microscope with $100 \times$ magnification and an eyepiece graticule was used. In each lamina, 5-20 $\mathrm{mm}^{2}$ were counted, if possible from adjacent areas. Counting was performed between the taeniae in the colon. Sometimes artefacts or incomplete preparation made it necessary to count the best areas available in the lamina. In rectum, specimens from various levels except the most distal $2 \mathrm{~cm}$ were studied. The mean of the counts at each level of the bowel in a subject is reported.

The diameter of nerve bundles in the primary myenteric plexus was measured using an image analyser (IPS 4.01, Alcatel, France). Specimens from all levels of the small bowel and colon were examined, and 10 longitudinal bundles were measured in each specimen.

In order to evaluate the age dependent variation, correlation was analysed. The relation between age and neurone density was not linear. However, the relation between the logarithms of these variables was linear and therefore used to analyse correlation. The results are reported as $r^{2}$ and $\mathrm{p}$ values; $\mathrm{p}<0.05$ was considered significant.

\section{Results}

Whole mount preparation facilitated visualisation of the meshwork of nerve bundles in the myenteric plexus, which comprises a primary, a secondary, and a tertiary plexus. There was a regular mesh of nerve bundles with ganglia (clusters of ganglion cells) at the intersections (primary plexus). There were nerve bundles connecting other bundles of the primary plexus without entering ganglia (the secondary plexus). In the space between the nerve 

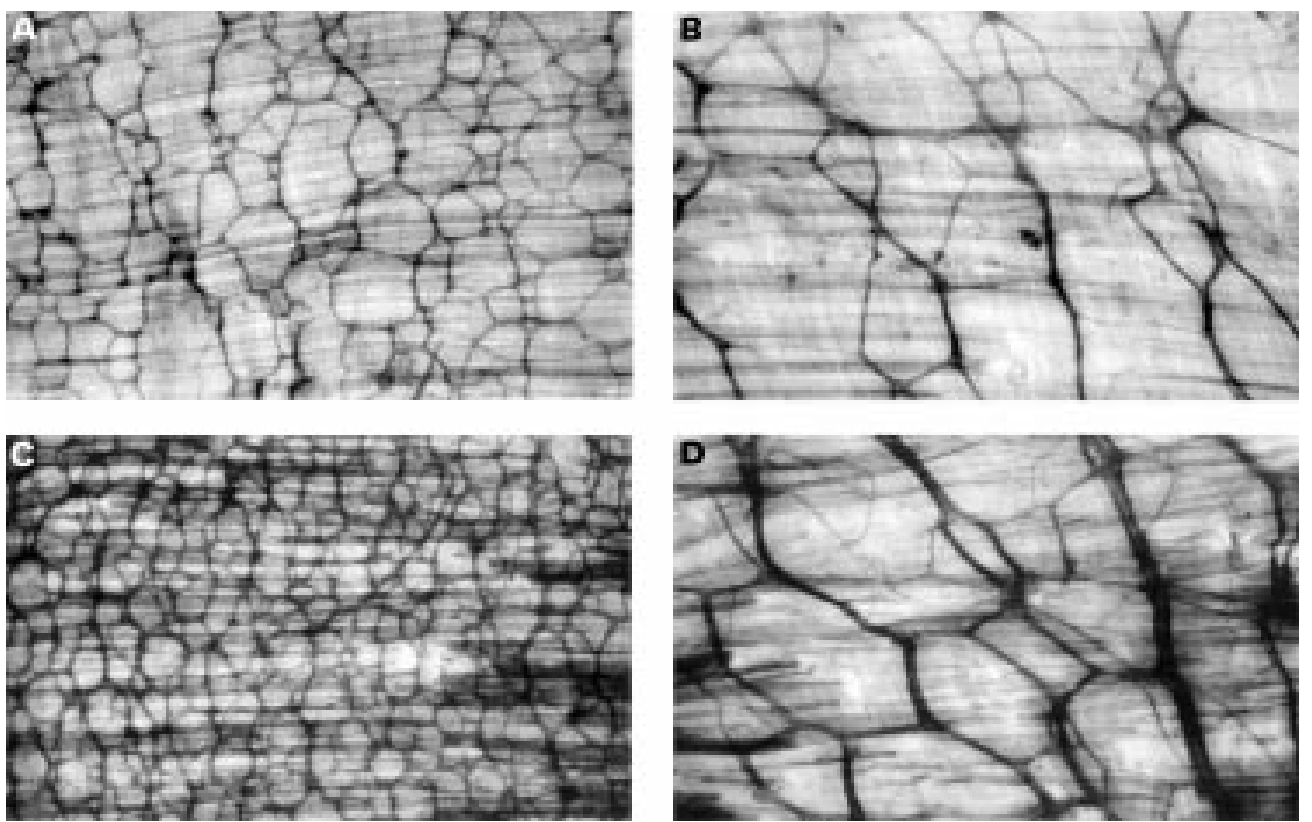

Figure 1. The myenteric plexus stained by NADPH diaphorase histochemistry. (A) fejunum in a 10 day old infant; (B) jejunum in a nine year old child; (C) distal colon in a 10 day old infant; (D) distal colon in a nine year old child. Original magnification $\times 16$.

bundles and ganglia of the primary plexus, a meshwork of very thin bundles (the tertiary plexus) was seen.

The morphology of the primary myenteric plexus varied between different levels of the gastrointestinal tract and with age. During infancy and childhood, the meshwork became less dense with increasing age (fig 1). The density of the meshwork increased in a distal direction, and was highest in the sigmoid colon and proximal rectum (figs $1 \mathrm{~A}, \mathrm{C}$ ). In the lower parts of rectum, the meshwork had a less compact appearance, with small ganglia and fibres extending in a longitudinal direction.

Figure 2 illustrates the mean diameter of longitudinal nerve bundles of the primary myenteric plexus at different levels of the gastrointestinal tract. A significantly increased mean bundle diameter was found with age in

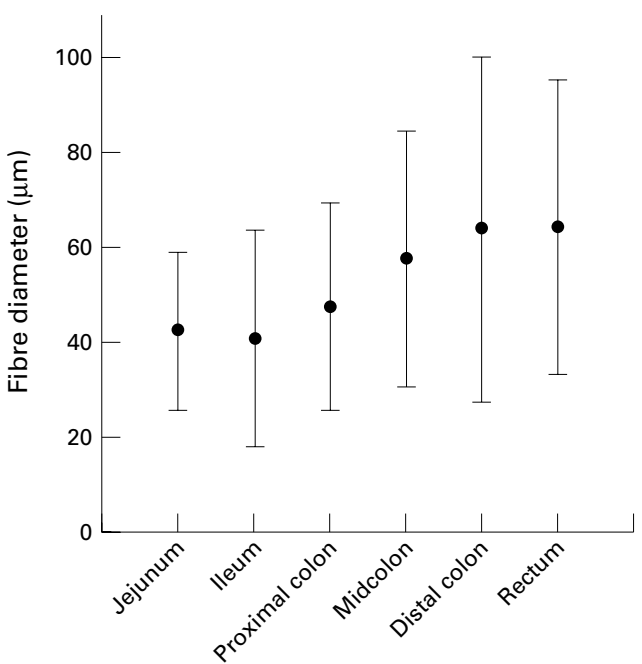

Figure 2 Mean diameter (SD) of nerve bundles in the myenteric plexus at different levels of the small and large intestine. jejunum $\left(r^{2}=0.659, \mathrm{p}<0.001\right)$, ileum $\left(r^{2}=0.785\right.$, $\mathrm{p}<0.001)$, midcolon $\left(r^{2}=0.396, \mathrm{p}<0.01\right)$, and rectum $\left(r^{2}=0.713, \mathrm{p}<0.001\right)$, but not in proximal $\left(r^{2}=0.134, \mathrm{p}=0.12\right)$ and distal colon $\left(r^{2}=0.189, \mathrm{p}=0.055\right)$. The mean diameter increased slightly distally and the variation in nerve bundle diameter was larger in the distal parts of the bowel, which was probably explained by the occurrence of occasional, longitudinal nerve bundles of very large diameter found from midcolon to rectum (fig 3A). The intensity of NADPH diaphorase activity in these thick nerve bundles appeared to be lower than in thinner nerve bundles. Nerve cell clusters were localised directly adjacent to these thick nerve bundles, whereas other clusters had connections with the nerve bundles via short strands. Occasionally, these nerve bundles could be seen entering the intermuscular space through the longitudinal muscle layer.

Remaining adherent circular muscle fibres were seen in almost all whole mount preparations, which were composed predominantly of the longitudinal muscle layer and the myenteric plexus. These circular muscle fibres contained a large number of regularly distributed NADPH diaphorase positive thin nerve bundles parallel with the muscle fibres (fig 3B). Occasionally, NADPH diaphorase positive cells were seen in the circular muscle layer, which were often spindle shaped cells. In the finely meshed tertiary plexus, abundant NADPH diaphorase positive thin bundles were also visible.

The NADPH diaphorase positive cells confined to the myenteric plexus were localised in ganglia at intersections of nerve bundles, although isolated neurones or small nerve cell clusters were commonly seen along the bundles. The morphology of the NADPH diaphorase positive neurones varied with age. In childhood, relatively large cells with easily 

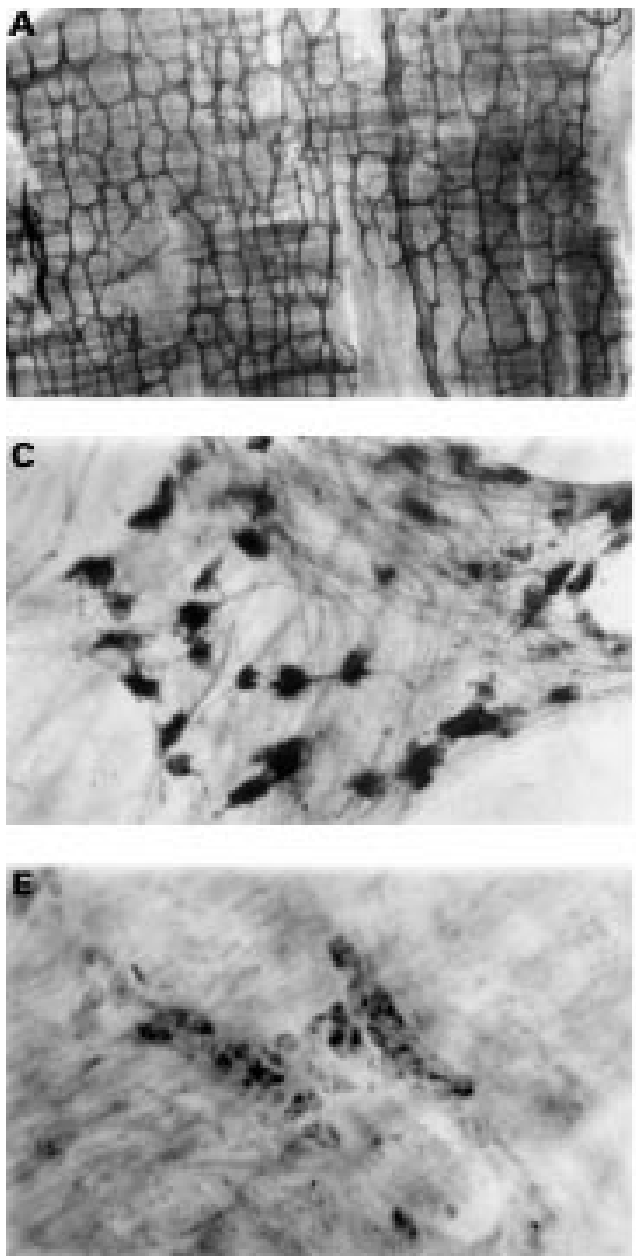

distinguished processes similar to Dogiel type I neurones predominated (fig $3 \mathrm{C}$ ). ${ }^{18}$ However, in the newborn period and infancy, small, round or irregularly shaped cells with less obvious processes were common (fig 3D).

Figure 4 illustrates the density of NADPH diaphorase positive nerve cells per $\mathrm{cm}^{2}$. A linear relation was found between the logarithms of age and neurone density, which was used for the analysis of correlation. The age dependent decrease in nerve cell density was significant at all levels of the small bowel, colon, and rectum when the correlation was evaluated (jejunum, $\mathrm{n}=19, r^{2}=0.557, \mathrm{p}<0.001 ;$ ileum, $\mathrm{n}=18$, $r^{2}=0.456, \mathrm{p}<0.01 ;$ proximal colon, $\mathrm{n}=16$, $r^{2}=0.542, \mathrm{p}<0.01$; midcolon, $\mathrm{n}=18, r^{2}=0.459$, $\mathrm{p}<0.01$; distal colon, $\mathrm{n}=17, r^{2}=0.544$, $\mathrm{p}<0.001$; rectum; $\mathrm{n}=13, r^{2}=0.318, \mathrm{p}<0.05 ; \mathrm{n}$ represents the number of cases in which it was possible to make whole mount preparations satisfactory for counting). The nerve cell density was higher in colon than in small bowel in all age groups. In the premature cases, the

Table 1 Neurone density in premature infants

\begin{tabular}{lllll}
\hline Case no & fejunum & Proximal colon & Distal colon & Rectum \\
\hline 1 & 22283 & 34600 & - & 31240 \\
2 & 28583 & 26140 & 36340 & -
\end{tabular}

NADPH diaphorase histochemistry of the myenteric plexus in two premature infants (expressed as NADPH diaphorase positive cells $/ \mathrm{cm}^{2}$ ).
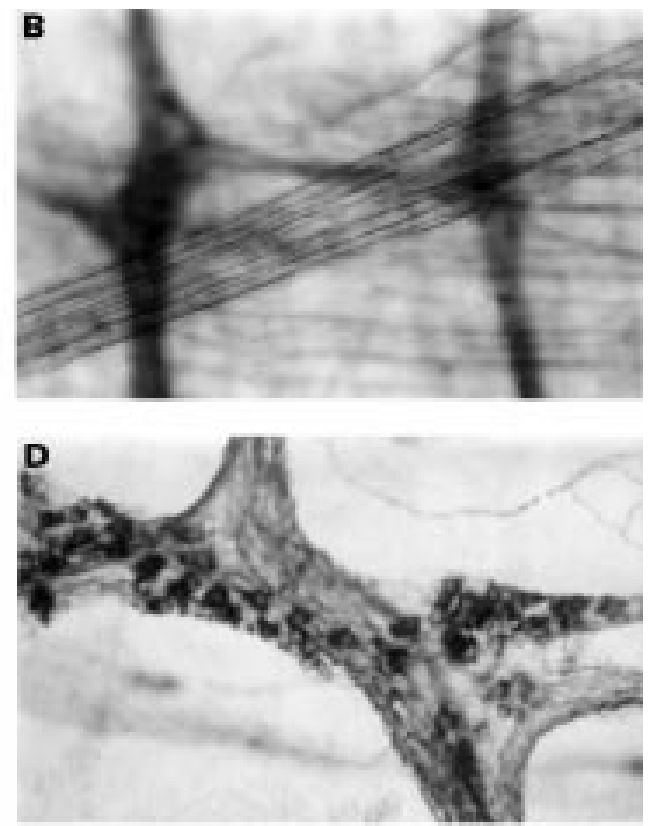

Figure 3 (A) An intramural pelvic nerve bundle in the rectal myenteric plexus of a newborn (NADPH diaphorase, original magnification $\times 16$ ). (B) $N A D P H$ diaphorase positive nerve bundles in the circular muscle layer. In the background the myenteric plexus is visible out of focus (original magnification $\times 100)$. (C) Mature ganglion cells in the myenteric plexus of a nine year old child (NADPH diaphorase, original magnification $\times 250$ ). (D) Small, relatively immature ganglion cells in the myenteric plexus of a newborn (NADPH diaphorase, original magnification $\times 250$ ). (E) Ganglion cells stained by cuprolinic blue in the jejunal myenteric plexus of a two year old child (original magnification $\times 250$ ).

nerve cell density was estimated in jejunum, proximal colon, distal colon, and rectum (see table 1).

The NADPH diaphorase positive neurones constitute a subpopulation of the total number of neurones in the myenteric plexus. We estimated the density of the total nerve cell population in the myenteric plexus in 14 specimens from jejunum or ileum with cuprolinic blue staining (fig 3E). Comparing these figures with the number of NADPH diaphorase positive cells in specimens from the same level in the same subject, $34 \%$ (SD $8.4 \%$ ) of the whole nerve cell population was found to be NADPH diaphorase positive. A slight but significant $\left(r^{2}=0.427, \mathrm{p}<0.05\right)$ decrease in the percentage from about $40 \%$ in neonates to $25-30 \%$ in older subjects was found.

In the aganglionic portion of the colon in the four patients with HD the principal abnormality was the total loss of the meshwork pattern, and NADPH diaphorase positive cells were absent, whereas thick nerve bundles of various directions were obvious. These fibres stained more weakly than fibres in the primary myenteric plexus in the ganglionic part of the colon. The myenteric plexus meshwork had a similar appearance in the ganglionic part of the colon in patients with HD to the distal colon in normal subjects of the same age. In the distal part of ganglionic bowel, the transition zone, thick nerve bundles which stained relatively weakly 

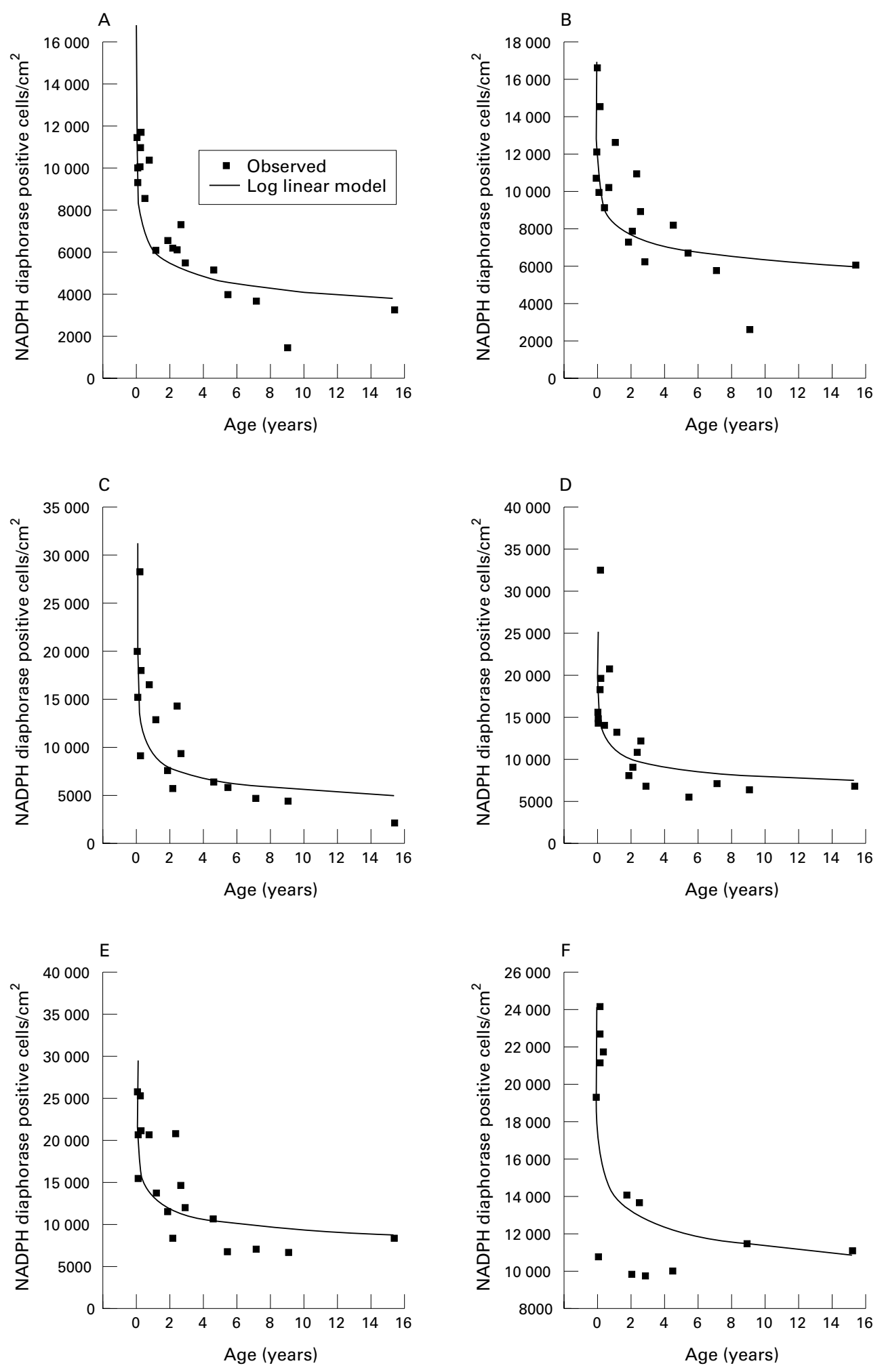

Figure 4 Density of NAPDH diaphorase positive nerve cells in the myenteric plexus. (A) jejunum; (B) ileum; (C) proximal colon; (D) midcolon; (E) distal colon; (F) rectum.

were seen and the meshwork appeared more irregular with smaller ganglia. In the ganglionic part of the colon, the NADPH diaphorase positive nerve bundles in the circular muscle layer were similar to those in the normal cases; these bundles were absent in the aganglionic colon.

\section{Discussion}

Strong evidence exists for $\mathrm{NO}$ as a messenger of NANC inhibitory neurotransmission in the human colon $^{19}{ }^{20}$ and internal anal sphincter. ${ }^{21}$ Previously, vasoactive intestinal peptide (VIP) ${ }^{22}$ and adenosine triphosphate $(\mathrm{ATP})^{23}$ have been suggested as putative transmitters in NANC 
inhibitory nerves, although evidence has been presented casting doubt on these hypotheses. ${ }^{24}{ }^{25}$ Recently, it was suggested that VIP is the primary relaxant transmitter, but that NO amplifies the relaxant effect of VIP in muscle cells and acts presynaptically to enhance the release of VIP. ${ }^{26}$ VIP has also been suggested to increase $\mathrm{NO}$ production by myenteric neurones. ${ }^{27}$ Other investigators have found that two messengers appear to be involved in NANC neurotransmission in human colon, ${ }^{19}{ }^{20}$ and suggested that ATP may have a role in addition to NO. ${ }^{19}$ With the recognition of the prominence of $\mathrm{NO}$ in gut innervation its role in the gastrointestinal tract (normal and pathological) needs to be defined.

The role of $\mathrm{NO}$ as a neurotransmitter in the enteric nervous system was supported by immunohistochemical studies showing expression of nitric oxide synthase (NOS) in neurones of the myenteric plexus. ${ }^{28}$ In 1983 , Scherer-Singler and colleagues ${ }^{2}$ described the enzymatic reduction of nitroblue tetrazolium to an intensely blue, water insoluble salt by nicotinamide adenine dinucleotide phosphate (reduced form, NADPH) diaphorase in a population of neurones. This NADPH diaphorase activity was shown to colocalise with NOS in the brain and peripheral neuronal tissue. ${ }^{34}$ Complete colocalisation of NOS immunoreactivity and NADPH diaphorase staining has been reported in the porcine ${ }^{29}$ and canine ${ }^{30}$ colon. A high degree of colocalisation, about $90 \%$, has also been reported in the human colon, ${ }^{31}{ }^{32}$ indicating that NADPH diaphorase histochemistry is an accurate marker of NOS immunoreactivity in the human enteric nervous system.

Gut innervation has a complex, three dimensional structure which is difficult to appreciate on thin sections. The whole mount preparation is an elegant technique for visualisation of the myenteric plexus. It provides a method for study of the three dimensional morphology of the meshwork of nerve fibres and neurones in detail. Several investigators have used the technique in specimens from the human gastrointestinal tract with various staining methods ranging from silver impregnation to enzyme histochemistry and immunocytochemistry. ${ }^{33-41}$ Routine techniques for immunohistochemistry and enzyme histochemistry in sections often require modifications in order to give satisfactory results in whole mount preparations, which is due to the thickness of the tissue.

Our results show that considerable changes occur in the human myenteric plexus postnatally. The density of NADPH diaphorase positive ganglion cells decreases significantly and the meshwork of fibres becomes less dense during the first years of life. In the individual case, the density of ganglion cells increases and the meshwork becomes denser in the distal direction from the jejunum to the distal colon and rectum.

In conventional sections, several investigators have described the normal nerve cell density in the human myenteric plexus. Schuffler and colleagues ${ }^{42}$ found 27.8 nerve cells per 100 $\mathrm{mm}$ smooth muscle, whereas Ikeda and colleagues ${ }^{43}$ found that more than 30 nerve cells per $10 \mathrm{~mm}$ was normal. Smith ${ }^{44}$ found seven nerve cells per $\mathrm{mm}$ smooth muscle, which is more than 20 times the density described by Schuffler et al. On the other hand, Meier-Ruge and colleagues ${ }^{45}$ found 756 ganglion cells per $10 \mathrm{~mm}$ muscle, which is 10 times the density described by Smith. There is no obvious reason for the huge variation between these reports but they are probably related to section thickness and the various techniques used.

In whole mount preparations, estimations of the nerve cell density in the myenteric plexus have been provided in various species. ${ }^{46} 47$ However, information is scanty regarding the human gastrointestinal tract, ${ }^{36}{ }^{48}{ }^{49}$ and this is to our knowledge the first attempt to describe systematically the density of nerve cells in the myenteric plexus of human small bowel and colon in whole mount preparations. Neurone density is an important parameter for evaluation of the enteric nervous system. The histological features of IND are mainly confined to the submucous plexus. However, Meier-Ruge ${ }^{9}$ in his original description also found hyperplasia of the myenteric plexus. On the other hand, more recent reports indicate that IND may be associated with hypoganglionosis of the myenteric plexus. ${ }^{12}$ Rarely, isolated hyperganglionosis of the myenteric plexus without submucous abnormalities, has been described. ${ }^{50}$ Hypoganglionosis of the myenteric plexus is also rare as an isolated condition and the incidence is about $10 \%$ of all cases with enteric nervous system malformations. ${ }^{12}$ The diagnosis usually requires full thickness biopsy samples. A clear definition of disorders such as hyperganglionosis and hypoganglionosis requires knowledge of the normal neurone density.

NADPH diaphorase staining, described by Gabella, ${ }^{51}$ has been one of the techniques suggested to stain all nerve cells in the enteric nervous system. However, using a nerve cell body antiserum, NADPH diaphorase histochemistry was found to stain about $80 \%$ of the nerve cell bodies. ${ }^{52}$ General neuronal markers such as neurone specific enolase (NSE) or protein gene product (PGP) 9.5 are difficult to use for neurone counting as the immunoreactivity is also expressed in nerve processes, and the nerve cell bodies may be difficult to distinguish. ${ }^{14}$ This is also a problem using NADPH diaphorase histochemistry for cell counting. Furthermore, in rat intestine, PGP 9.5 has been estimated to stain only about $80 \%$ of the total neuronal population. ${ }^{53}$

Recently, cuprolinic blue was suggested to stain the whole population of nerve cells in the myenteric plexus. ${ }^{17}$ In the presence of a high concentration of $\mathrm{MgCl}_{2}$, cuprolinic blue specifically stains single stranded RNA, ${ }^{16}{ }^{54}$ and thus acts as a ribosomal stain. Glial cells, interstitial cells of Cajal, and smooth muscle cells contain few ribosomes, and cuprolinic blue has been suggested to provide a very specific neuronal marker in the myenteric plexus. ${ }^{14}$ The staining intensity in our cases was, however, 
relatively weak and counting was difficult. Particularly in specimens from colon, the high density of cells in colonic myenteric plexus resulted in considerable overlapping and difficulties in distinguishing the cells from each other so that estimates of the relative proportion of cuprolinic blue to NADPH cells represents an approximation rather than precise counting. We found, comparing specimens from small bowel, that about $34 \%$ of the cuprolinic blue positive cells were NADPH diaphorase positive. This figure is similar to the $30 \%$ reported by Gaumnitz et al..$^{55}$ Conversely, Porter et al recently reported that $64 \%$ of the neurones in the human myenteric plexus were choline acetyltransferase immunoreactive or cholinergic. ${ }^{56}$

We found that the morphology of the primary myenteric plexus meshwork, stained with NADPH diaphorase histochemistry, is similar to that described by Kumar and Phillips, ${ }^{37}$ who used a silver staining technique. However, they reported no obvious differences between the adult cases and neonates, which is in sharp contrast to our findings. In humans, Stach $^{57}$ described nerves originating from the pelvic plexus ascending along the myenteric plexus in the distal part of the colon. These appeared identical to the thick, longitudinal nerve bundles we found which showed weak NADPH staining. Christensen and colleagues $^{58}$ reported similar nerves, which they called shunt fascicles, in the colon in eight mammal species and suggested that they may serve as pathways for neural signals between the rectum and more proximal parts of the colon. Results from neurophysiological studies in dogs by Fukai and Fukada ${ }^{59}$ supported this hypothesis. These authors used the name intramural pelvic nerves, which has been suggested as the most appropriate term. ${ }^{60}$ These nerves contain myelinated fibres ${ }^{58}$ giving branches to some ganglia while others are bypassed. ${ }^{61}$ Kumar and Phillips ${ }^{37}$ described intramural pelvic nerves in humans, ascending from the distal rectum into the midcolon with equal frequency in neonatal and adult bowel, which is in accordance with our findings. Intramural pelvic nerves appear to be of extrinsic origin, providing neural connections between the intrinsic and extrinsic parts of the enteric nervous system. ${ }^{61}$ Visualisation of nerves entering the intermuscular layer through the longitudinal muscle is morphological evidence for an extrinsic origin of the intramural pelvic nerves. Christensen and colleagues $^{58}$ have suggested previously that the "shunt bundles" are of extrinsic origin. The intramural pelvic nerves appear similar to the hypertrophic nerve bundles observed in aganglionic bowel, which also are weakly NADPH diaphorase positive. These hypertrophic nerve trunks in HD have been shown to have an extrinsic origin. ${ }^{62}$

Brandt and colleagues ${ }^{63}$ studied the ontogeny of NADPH diaphorase positive cells in the human gastrointestinal tract and found nitrergic neurones at all studied levels of the gastrointestinal tract at 12 weeks' gestation. At 14 weeks the NADPH diaphorase positive cells became evident in the submucosa, when also an increasing number of fibres were positive in the circular muscle layer. At 23 weeks' gestation, the distribution of nitrergic innervation was similar to that observed after birth.

Timmermans and colleagues ${ }^{36}$ compared the density of NADPH diaphorase positive neurones in a fetus, 32 weeks postconceptional age, and a two month old infant. In the myenteric plexus in the fetal proximal jejunum they found 31742 neurones $/ \mathrm{cm}^{2}$, compared with 3710 neurones $/ \mathrm{cm}^{2}$ in the two month old infant. The neurone density was considerably higher in the proximal colon where it was 63418 neurones $/ \mathrm{cm}^{2}$ and 8878 neurones $/ \mathrm{cm}^{2}$ in the fetus and the two month old infant, respectively. These figures indicate an earlier occurrence of the decrease in density of NADPH diaphorase positive neurones compared with our results, where the decrease continued during the first three to four years of life. We also found that the morphology of nerve cells changed during the first years of life from relatively small cells with small processes, which were difficult to distinguish, to large cells with obvious axons and dendrites. Smith ${ }^{64}$ studied the human enteric nervous system from the early embryonic period and also found a continuous maturation of the ganglia throughout childhood.

One methodological problem associated with calculation of neurone density is whether the area of the processed specimen is identical to the bowel surface area in vivo. In our studies the specimens were fixed without any stretching. When the whole mounts were prepared, the specimens were pinned flat and slightly stretched, which is necessary for dissection. However, the specimens regained their original postfixation size when the pins were released. The important point is the degree of stretching at time of fixation as fixation makes the specimens much less plastic. Furthermore, we performed experiments in order to estimate how much stretching would influence the results (unpublished observations). It was found that fixation with maximally stretched specimens decreased the neurone density to about $80 \%$ of the figures in specimens which were not stretched during fixation. This indicates that the influence of stretching on the results is probably limited as the differences, with respect to neurone density, between neonates and older children was three- or fourfold. In the present study the procedure was identical in all cases and thus the differences between cases at various ages could hardly be explained by the degree of stretching.

Several possibilities may explain the decreasing number of NADPH diaphorase positive cells per surface area. Growth of the bowel with increasing surface area probably explains part of the decreasing neurone density. Gabella, ${ }^{46}$ using NADH diaphorase histochemistry, compared the neurone density in the myenteric plexus in newborn and adult rats and found that a considerable decrease occurred. However, the total number of nerve cells in the myenteric plexus was also estimated and was found to increase. It is still unknown whether 
the age dependent decrease in the density of NADPH diaphorase positive neurones in humans correlates with an increased total cell number. In the central nervous system, about twice as many neurones as are required by the adult nervous system are produced by neurogenesis. The reduction in cell number occurs by apoptosis, programmed cell death, which is a normal way for correction of errors in nervous system development and removal of redundant neurones. ${ }^{65}$ Other possibilities for the decreasing density of NADPH diaphorase positive neurones are that the subpopulation of NADPH diaphorase positive neurones is larger during development than later on or that another cell type is NADPH diaphorase positive during development. Our results indicate that the proportion NADPH diaphorase positive cells relative to cuprolinic blue staining cells decreases only slightly, from about $40 \%$ to 25-30\%, during infancy and childhood, casting doubt on the hypothesis that the size of the NADPH diaphorase positive subpopulation changes enough to explain the large decrease in NADPH diaphorase positive cell density. Timmermans and colleagues ${ }^{36}$ reported a high degree of colocalisation between NOS immunoreactivity and NADPH diaphorase positive cells in human fetuses and newborns. In the myenteric plexus, circular muscle layer and submucosa, these authors found small round or oval cells, which were NOS immunoreactive and NADPH diaphorase positive but did not stain for either PGP 9.5 or NSE, and it was suggested that they may be interstitial cells of Cajal, glial cells, or macrophage-like cells. Evidence exists that NOS activity can be induced in glial cells by cytokines. ${ }^{66}$ Interstitial cells of Cajal may express the endothelial isoform of constitutive $\mathrm{NOS}^{67}$; however, Xue and colleagues ${ }^{68}$ and Vanderwinden and colleagues ${ }^{69}$ have reported that interstitial cells do not stain for NADPH diaphorase.

In conclusion, NADPH diaphorase positive or nitrergic ganglion cells and nerve bundles play a major role in the human enteric nervous system. NADPH diaphorase positive neurones account for about $34 \%$ of the total number of enteric neurones. The density of NADPH diaphorase positive neurones in the myenteric plexus decreases during the first years of life at all levels of small bowel, colon, and rectum. The meshwork of the myenteric plexus also becomes sparser with age and a continuous maturation of the nerve cell morphology can be observed. These findings indicate that development is still an ongoing process in the postnatal enteric nervous system, which applied to the clinical setting implies that interpretation of enteric nervous system pathology is dependent on age of the patient.

Dr T Wester was supported by HRH Crown Princess Louisa's Association for Child Medical Care, Åke Wiberg's Foundation for Scientific Research, and the Swedish Medical Research Council.

1 Sanders KM, Ward SW. Nitric oxide as a mediator of nonadrenergic noncholinergic neurotransmission. Am f Physiol 1992;262: G379-92. 2 Scherer-Singler U, Vincent SR, Kimura H, et al. Demondiaphorase histochemistry. F Neurosci Methods 1983;9:22934 .

3 Dawson TM, Bredt DS, Fotuhi M, et al. Nitric oxide synthase and neuronal NADPH diaphorase are identical in brain and peripheral tissues. Proc Natl Acad Sci USA 1991; 88:7797-801.

4 Hope BT, Michael GJ, Knigge KM, et al. Neuronal NADPH diaphorase is a nitric oxide synthase. Proc Natl Acad Sci USA 1991;88:2811-14.

5 Vanderwinden J-M, Mailleux P, Schiffmann SN, et al. Nitric oxide synthase activity in infantile hypertrophic pyloric stenosis. N Engl f Med 1992;327:511-15.

6 Vanderwinden J-M, De Laet M-H, Schiffmann SN, et al. Nitric oxide synthase distribution in the enteric nervous system of Hirschsprung's disease. Gastroenterology 1993; 105:969-73.

7 Kobayashi H, O'Briain DS, Puri P. Lack of expression of NADPH-diaphorase and neural cell adhesion molecule NADPH-diaphorase and neural cell adhesion molecule (NCAM) in colonic muscle of patients
disease. F Pediatr Surg 1994;29:301-4.

disease. F Pediatr Surg 1994;29:301-4.
8 Kobayashi H, Hirakawa H, Puri P. Intestinal neuronal dysplasia. Is acetylcholinesterase histochemistry adequate for diagnosis? In: XXXXI Annual International Congress of British Association of Paediatric Surgeons, Rotterdam, 1994.

9 Meier-Ruge W. Über ein Erkrankungsbild des Colon mit Hirschsprung-Symptomatik. Vehr Dtsch Ges Pathol 1971; 55:506-10.

10 Lake BD. Intestinal neuroneal dysplasia. Why does it only occur in parts of Europe? Virchows Arch 1995;426:537-9.

1 Milla PJ, Smith VV. Intestinal neuronal dysplasia. $\mathcal{F}$ Pediatr Gastroenterol Nutr 1993;17:356-7.

12 Meier-Ruge W, Gambazzi F, Käufeler RE, et al. The neuropathological diagnosis of neuronal intestinal dysplasia (NID B). Eur f Pediatr Surg 1994;4:267-73.

13 Meier-Ruge WA, Brönnimann PB, Gambazzi F, et al. Histopathological criteria for intestinal neuronal dyplasia of the submucosal plexus (type B). Virchows Arch 1995;426:549-56

14 Karaosmanoglu T, Aygun B, Wade PR, et al. Regional differences in the number of neurones in the myenteric plexus of the guinea pig small intestine and colon: an evaluation of markers used to count neurones. Anat Rec 1996;244:470-80.

15 Wester T, O'Briain DS, Puri P. NADPH diaphorasecontaining nerve fibers and neurones in the myenteric plexus are resistant to postmortem changes. Arch Pathol Lab Med 1998;122:461-6.

16 Mendelson D, Tas J, James J. Cuprolinic blue: a specific dye for single stranded RNA in the presence of magnesium Histochem f 1983;15:1113-21.

17 Heinicke EA, Kiernan JA, Wijsman J. Specific, selective, and complete staining of neurones of the myenteric plexus, using cuprolinic blue. $\mathcal{F}$ Neurosci Methods 1987;21:45-54.

18 Furness JB, Costa M (eds). Cytoarchitectonics of the enteric nervous system. In: The enteric nervous system. New York, NY: Churchill Livingstone, 1987:26-54.

19 Boechxstaens GE, Pelckmans PA, Herman AG, et al. Involvement of nitric oxide in the inhibitory innervation of the human isolated colon. Gastroenterology 1993;104:6907.

20 Keef KD, Du C, Ward SM, et al. Enteric inhibitory neural regulation of human colonic circular muscle: role of nitric oxide. Gastroenterology 1993;105:1009-16.

21 O'Kelly T, Brading A, Mortensen N. Nerve mediated relaxation of the human internal anal sphincter: the role of relaxation of the human internal ana
nitric oxide. Gut 1993;34:689-93.

22 Grider JR, Cable MB, Said SI, et al. Vasoactive intestinal peptide as a neural mediator of gastric relaxation. $A m \mathcal{F}$ Physiol 1985;248:G73-8.

23 Burnstock G, Campbell G, Satchell D, et al. Evidence that adenosine triphosphate or a related nucleotide is the transmitter substance released by nonadrenergic inhibitory nerves in the gut. Br F Pharmacol 1970;40:668-88.

24 Daniel EE, Helmy-Elkholy A, Jager LP, et al. Neither a purine nor VIP is the mediator of inhibitory nerves of opossum oesophageal smooth muscle. F Physiol 1983;336: 243-60

25 Westfall DP, Hogaboom GK, Colby J, et al. Direct evidence against a role of ATP as the nonadrenergic noncholinergic
inhibitory neurotransmitter in guinea pig tenia coli. Proc Natl Acad Sci USA 1982;79:7041-5.

26 Grider JR, Murthy KS, Jin J-G, et al. Stimulation of nitric Grider JR, Murthy KS, Jin J-G, et al. Stimulation of nitric
oxide from muscle cells by VIP: prejunctional enhanceoxide from muscle cells by VIP: prejunctional enh
ment of VIP release. Am $\mathcal{F}$ Physiol 1992;262:G774-8.

27 Chadker S, Rattan S. Evidence for VIP-induced increase in NO production in myenteric neurones of opossum internal anal sphincter. Am F Physiol 1996;270:G492-7.

28 Bredt DS, Hwang PM, Snyder SH. Localisation of nitric oxide synthase indicating a neural role for nitric oxide. Nature 1990;347:768-70.

29 Barbiers M, Timmermans J-P, Scheuermann DW, et al. Distribution and morphological features of nitrergic neurones 34.

30 Ward SM, Xue C, Shuttleworth CW, et al. NADPH diaphorase and nitric oxide synthase colocalization in enteric neurones of canine proximal colon. Am f Physiol 1992;263: G277-84

31 O'Kelly TJ, Davies JR, Brading AF, et al. Distribution of nitric oxide synthase containing neurones in the rectal myenteric plexus and anal canal: morphological evidence 
that nitric oxide mediates the recto-anal inhibitory reflex. Dis Colon Rectum 1994;37:350-7.

32 Matini P, Mannin $190,37: 350-7$. ing neurones in the human colon: an immunohistochemical and histoenzymatical study. Neurosci Lett 1995;193:1720.

33 Llewellyn-Smith IJ, Costa M, Furness JB. Light and electron microscopic immunocytochemistry of the same nerves from whole-mount preparations. $\mathcal{f}$ Histochem Cytochem 1985;33:857-66.

34 Krammer H-J, Karahan ST, Sigge W, et al. Immunohistochemistry of markers of the enteric nervous system in whole-mount preparations of the human colon. Eur f Pediatr Surg 1993;4:274-8.

35 Krammer H-J, Zhang M, Kühnel W. Distribution of NADPH-diaphorase-positive neurones in the enteric nervous system of the human colon. Ann Anat 1994:176:13741 .

41.

Timmermans J-P, Barbiers M, Scheuermann DW, et al. Nitric oxide synthase immunoreactivity in the enteric nervous system of the developing human digestive tract. Cell Tissue Res 1994:275:235-45.

37 Kumar D, Phillips SF. Human myenteric plexus: confirmation of unfamiliar structures in adults and neonates. Gastroenterology 1989;96:1021-8.

38 O'Kelly TJ, Davies JR, Tam PKH, et al. Abnormalities of nitric-oxide-producing neurones in Hirschsprung's disease: morphology and implications. F Pediatr Surg 1994 29:294-300.

39 Fekete E, Resch BA, Benedeczky I. Histochemical and ultrastructural features of the developing enteric nervous system of the human foetal small intestine. Histol Histopathol 1995;10:127-34.

40 Mebis J, Penninckx F, Geboes K, et al. Neuropathology of Hirschsprung's disease. Hepatogastroenterology 1990;37: 596-600.

41 Ferri GL, Botti PL, Vezzadini P, et al. Peptide-containing innervation of the human intestinal mucosa. An immunoinnervation of the human intestinal mucosa. An immunocytochemical study on whol
chemistry 1982;76:413-20.

42 Schuffler MD, Bird TD, Sumi SM, et al. A familial neuronal disease presenting as intestinal pseudoobstruction. Gastrodisease presenting as intestin
enterology 1978;75:889-98.

43 Ikeda K, Goto S, Nagasaki A, et al. Hypogenesis of intestinal ganglion cells: a rare cause of intestinal obstruction simulating aganglionosis. $Z$ Kinderchir 1988;43:52-3

44 Smith VV. Intestinal neuronal density in childhood: a baseline for the objective assessment of hypo- and hyperganglionosis. Pediatr Pathol 1993;13:225-37.

45 Meier-Ruge W, Morger R, Rehbein F. Das hypoganglionäre Megakolon als Begleitkrankheit bei Morbus Hirschsprung. $Z$ Kinderchir 1970;8:254-64.

46 Gabella G. Neuron size and number in the myenteric plexus of the newborn and adult rat. F Anat 1971;109:81-95.

47 Gabella G. The number of neurones in the small intestine of mice, guinea-pigs and sheep. Neuroscience 1987;22:737-52.

48 Ferraz de Carvalho CA, Rodrigues de Souza R, Oliveira CA, et al. A quantitative study on the myenteric plexus of the distal end of the duodenum and the proximal part of the distal end of the duodenum and the proximal part of the

49 de Souza RR, Moratelli HB, Borges N. Age-induced nerve cell loss in the myenteric plexus of the small intestine in man. Gerontology 1993;39:183-8.
50 Gittes GK, Kim J, Yu G, et al. Severe constipation with diffuse intestinal myenteric hyperganglionosis. F Pediatr Surg $1993 ; 28: 1630-2$

51 Gabella G. Detection of nerve cells by a histochemical technique. Experientia 1969;25:218-19.

52 Young HM, Furness JB, Sewell P, et al. Total numbers of neurones in myenteric ganglia of the guinea-pig small intestine. Cell Tissue Res 1993;272:197-200.

53 Eaker EY, Sallustio JE. The distribution of novel intermediate filament proteins defines subpopulations of myenteric neurones in rat intestine. Gastroenterology 1994;107:66674.

54 Tas J, Mendelson D, Noorden CJF. Cuprolinic blue: a specific dye for single-stranded RNA in the presence of magnesium chloride. I. Fundamental aspects. Histochem $\mathcal{F}$ 1983;15:801-14.

55 Gaumnitz E, Sweet MA, Sengupta A, et al. Nitrergic and peptidergic innervations and their inter-relationship in human colon. Neuropeptides 1995;29:1-9.

56 Porter AJ, Wattchow DA, Brookes $\mathrm{SJH}$, et al. Choline acetyltransferase immunoreactivity in the human small and large intestine. Gastroenterology 1996;111:401-8.

57 Stach W. Über die in der Dickdarmswand aszendierenden Nervev des Plexus pelvinus und die Grense der vagalen und sakralparasympatischen Innervation. $Z$ Mikrosk-Anat Forsch 1971;84:65-90.

58 Christensen J, Stiles MJ, Rick GA, et al. Comparative anatomy of the myenteric plexus of the distal colon in eight mammals. Gastroenterology 1984;86:706-13.

59 Fukai K, Fukada H. The intramural pelvic nerves in the colon of dogs. F Physiol 1984;354:89-98.

60 Furness JB, Costa M (eds). Studies of neuroneal circuitry of the enteric nervous system. In: The enteric nervous system. New York, NY: Churchill Livingstone, 1987:111-36.

61 Christensen J. The motility of the colon. In: Johnson LR, ed. Physiology of the gastrointestinal tract. New York: Raven Press, 1994:991-1024.

62 Watanabe $\mathrm{Y}$, Ito $\mathrm{F}$, Ando $\mathrm{H}$, et al. Extrinsic nerve strands in the aganglionic segment of Hirschsprung's disease. $\mathcal{F}$ Pediatr Surg 1998;33:1233-7.

63 Brandt CT, Tam PKH, Gould SJ. Nitrergic innervation of the human gut during early fetal development. $\mathcal{F}$ Pediatr Surg 1996;31:661-4.

64 Smith B. Pre- and postnatal development of the ganglion cells of the rectum and its surgical implications. $\mathcal{F}$ Pediatr Surg 1968;3:386-91.

65 Oppenheim RW. Cell death during development of the nervous system. Anmu Rev Neurosci 1991;14:453-501.

66 Simmons ML, Murphy S. Induction of nitric oxide synthase in glial cells. $\mathcal{f}$ Neurochem 1992;59:897-905.

67 Xue C, Pollock J, Schmidt HHHW, et al. Expression of nitric oxide synthase by interstitial cells of the canine proximal colon. F Autonom Nerv Syst 1994;49:1-14.

68 Xue C, Ward SM, Shuttleworth W, et al. Identification of interstitial cells in canine proximal colon using NADH diaphorase histochemistry. Histochemistry 1993;99:373-84.

69 Vanderwinden J-M, Rumessen JJ, Liu H, et al. Interstitial cells of Cajal in human colon and in Hirschsprung's disease. Gastroenterology 1996;111:901-10. 